Plant Protection and Quarantine. 2018. Issue 64.

CZU: 632.937.12+934

M. BATCO, doctor habilitat

V. SUMENCOVA, doctor habilitat

E. IORDOSOPOL, doctor habilitat

Institute of Genetics, Physiology and Plant Protectionof Republic of Moldova

\title{
THE SENSITIVITY OF SOME SPECIES OF ENTOMOACARIFAGES TO THE INSECTOCARICIDES USED IN THE PROTECTION OF APPLE CULTURE
}

The apple orchard populations of acariphagous (Stethorus punctillum Weise, Chrysopa carnea Steph, and mite-predators Amblyseius andersoni Chan, Metaseilus occidentalis Nesbit and Neoseiulus californicus Mc Gregor), which were at least 25 years under pesticide treatment, were studied. Our studies show that for these populations the least toxic pesticide is Avaunt, EC, Talstar 10 EC, Omite 30 WP, Confidor 200 SL and the most toxic pesticide is Vertimec 018 EC, Dursban 480 EC for both entomophagous. BI-58 New is slightly toxic for the larvae of $C$. carnea and highly toxic for N. californicus in laboratory culture. The orchard populations of acariphagous develop resistance to BI-58 New, Dursban 480 EC and Decis f-Luxx 025 EC, in the conditions of the prolong pesticide treatment. The discovery of natural populations of entomophagous resistant to pesticides is of high importance due to its potential practical use.

stethorus punctillum, Chrysopa carnea, Amblyseius andersoni,

Metaseilus occidentalis, Neoseiulus californicus, insecticide resistance

The efficiency of an integrated crop protection system for pests is wholly dependent on how the effect of pesticides is correlated with beneficial fauna. Useful fauna is a key element in these systems and requires caution.

If we analyze the consequences of the pesticides effect to harmful and beneficial species, then predators and parasites are recognized as more vulnerable. This is due to the fact that the enzymatic systems of the phytophagous species, unlike the entomophagous ones, are better adapted to the detoxification process as an answer to the action of the toxic compounds they encounter within the host plant. The degree of increased predators mobility in search of the host leads to advanced absorption of pesticides, which also leads to increased mortality. Finally, after some predators have survived chemical treatments, they can simply perish because of the absence or insufficiency of food [1]. In conclusion - the use of total pesticides 
should be abandoned, in favor of those which are tolerant to predators and parasites, in order to preserve the useful fauna in agrocoenoses.

This clause can be achieved through the competence of selecting of applied pesticides. In addition to the effectiveness of pesticides against pests, an important criterion is also their degree of environmental danger, taking into account the effect of pesticides on the main components of agroecosystems, including useful fauna. The use of pesticides, which would tolerate the "activity" of useful fauna, is an element of conservative biological control that in turn leads to the numerical reduction of chemical treatments necessary to keep pests below the economic threshold of damage.

Another important aspect, which improves the coexistence of useful fauna during chemical treatments, is the development of the resistance of the populations of entomophagous and predators to pesticides, which have been reported in scientific communications lately. Examples of success are the practical application of useful arthropod lines with high pesticide resistance as biological control agents in the integrated pest management [2]. The purpose of this paper is to evaluate the sensitivity of entomoacariphagous to insectoacaricides (IA), with different mechanisms of action, in apple orchard agrocoenosis.

Material and methods. In the researches were analyzed imago Stethorus punctillum Weise and predatory mites Ambliseius andersoni Chan, and Metaseilus occidentalis Nesbit, collected in agrocoenosis of apple culture in Bacioi commune, as well as larvae of age 1 and 2 (first generation) of Chrysopa carnea Steph, obtained from imago, which was collected in the same agrocoenosis. It was also analyzed the imago of Neoseiulus californicus McGregor, whose population is resistant to organophosphorus pesticides. It was obtained from the United States of America in 2004 and kept under laboratory conditions without being exposed to pesticides.

The contact action of IA on entomophagous and predatory mites was determined. The pesticide concentrations similar to the recommended consumption standards for use in apple protection systems have been experimented. The toxicity assessment was performed in accordance with IOBC/WPRS recommendations [2]: mortality of beneficial species $\leq 30 \%-$ as inoffensive (In), mortality $30-79 \%$ - poorly toxic (PT), 80-89 moderately toxic (MT) and mortality $\geq 90 \%$ - very toxic (VT). In the test of the resistance of the Stethorus punctillum population to insecticides LD 50 was determined.

Results and discussions. According to the results presented in Table 1, for adult individuals of $S$. punctillum and Ch. carnea larvae collected in the orchard with multiple chemical treatments over the years, only the Dursban insecticide had a very toxic action. The rest of investigated (IA) (Avaunt, EC, Talstar 10 EC, Decis f-Luxx 025 EC, Confidor 200 SL, Neorone 500 EC) at recommended doses for use have had an inoffensive or poorly toxic 


\section{The action of insectoacaricides on entomophagous in agrocoenosis of apple culture}

\begin{tabular}{|c|c|c|c|c|c|c|}
\hline \multirow[b]{2}{*}{ Product, s.a. } & \multicolumn{2}{|c|}{$\begin{array}{c}\text { Standard dose } \\
\text { of IA }\end{array}$} & \multicolumn{2}{|c|}{$\begin{array}{c}\text { Stethorus } \\
\text { punctillum, imago }\end{array}$} & \multicolumn{2}{|c|}{$\begin{array}{c}\text { Chrysopa carnea, } \\
\text { larvae }\end{array}$} \\
\hline & $\begin{array}{c}\text { By } \\
\text { product, } \\
\text { L/kg/ha }\end{array}$ & $\begin{array}{c}\text { After } \\
\text { s.a, } \\
\%\end{array}$ & $\begin{array}{l}\text { Mortality, } \\
\%\end{array}$ & $\begin{array}{c}\text { Grade } \\
\text { of } \\
\text { hurt }\end{array}$ & $\begin{array}{c}\text { Mortality, } \\
\%\end{array}$ & $\begin{array}{c}\text { Grade } \\
\text { of } \\
\text { hurt }\end{array}$ \\
\hline $\begin{array}{l}\mathrm{BI}-58 \mathrm{New}, \\
\text { (dimetoat) }\end{array}$ & 1.0 & 0.05 & 7 & (In) & 80 & (MT) \\
\hline $\begin{array}{l}\text { Talstar } 10 \mathrm{EC}, \\
\text { (bifentrin) }\end{array}$ & 0.4 & 0.005 & 25 & (In) & 0 & (In) \\
\hline $\begin{array}{l}\text { Decis f-Luxx } 025 \\
\text { EC, (deltametrin) }\end{array}$ & 1.0 & 0.005 & 0 & (In) & 0 & (In) \\
\hline $\begin{array}{c}\text { Confidor } 200 \mathrm{SL} \\
\text { (imidacloprid) }\end{array}$ & 0.3 & 0.006 & 15 & (In) & $\begin{array}{l}\text { It is not } \\
\text { determined }\end{array}$ & \\
\hline $\begin{array}{l}\text { Neorone } 500 \mathrm{EC}, \\
\text { (brompropilat) }\end{array}$ & 2.0 & 0.1 & 23 & (In) & 0 & (In) \\
\hline $\begin{array}{l}\text { Dursban } 480 \text { EC } \\
\text { (chlorpyrifos) }\end{array}$ & 1.5 & 0.1 & 85 & $(\mathrm{MT})$ & 100 & (VT) \\
\hline $\begin{array}{l}\text { FASTAC } 100 \text { EC, } \\
\text { (alfa- cipermetrin) }\end{array}$ & 0.3 & 0.003 & 0 & (In) & $\begin{array}{l}\text { It is not } \\
\text { determined }\end{array}$ & - \\
\hline $\begin{array}{l}\text { Avaunt EC } \\
\text { (indoxacarb) }\end{array}$ & 0.4 & 0.005 & 0 & (In) & 0 & (In) \\
\hline
\end{tabular}

effect. Vertimec 018 EC also caused long-lasting effects on Ch. carnea, resulting in deformed adults (up to 50\%) from treated larvae. The use of these insectoacaricides against pests will contribute to the maintenance of stabilization mechanisms of the biological balance in agrocoenosis. The exception of the analyzed products is BI-58 NEW, which is moderately toxic for Ch. carnea larvae.

During analyzing the resistance development process, it was determined that the $\mathrm{LD}_{50}$ of the Stathorus punctillum population, from chemically treated intensive apple orchard agrocoenosis, is 21 times higher than the $\mathrm{LD}_{50}$ of the sensitive population to Bi-58N and greater than 1000 times to the pyrethroid of synthesis Decis f-Luxx 025. Thus, these insecticides have become inoffensive to this entomophagous, as a result of the resistance developed over time.

The Avaunt EC, insecticide has proven to be less toxic, practically inoffensive for predator mites, while Omite $30 \mathrm{WP}$ and Dursban 480 EC are poorly toxic, and the most noxious - the new generation Vertimec 018 EC product. It is worth mentioning that the Dursban 480 EC product did not show toxic action on the mite $M$. occidentalis, which is explained 


\section{The action of insectoacaricides on predatory mites in agrocoenosis of apple culture}

\begin{tabular}{|c|c|c|c|c|c|c|c|}
\hline \multirow{3}{*}{ Product, s.a. } & \multirow{3}{*}{$\begin{array}{c}\text { concen- } \\
\text { tration } \\
\text { after } \\
\text { s.a, } \%\end{array}$} & \multicolumn{3}{|c|}{ M. occidentalis } & \multicolumn{3}{|c|}{ A. andersoni } \\
\hline & & \multicolumn{2}{|c|}{ Mortality, \% } & \multirow{2}{*}{$\begin{array}{l}\text { Grade } \\
\text { of hurt }\end{array}$} & \multicolumn{2}{|c|}{ Mortality, \% } & \multirow{2}{*}{$\begin{array}{l}\text { Grade } \\
\text { of hurt }\end{array}$} \\
\hline & & $24 \mathrm{~h}$ & $48 \mathrm{~h}$ & & $24 \mathrm{~h}$ & $48 \mathrm{~h}$ & \\
\hline $\begin{array}{l}\text { BI-58 New } \\
\text { (dimetoat) }\end{array}$ & 0.05 & 32 & 41 & $(\mathrm{PT})$ & 12 & 20 & (In) \\
\hline $\begin{array}{l}\text { Dursban } 480 \text { EC } \\
\text { (chlorpyrifos) }\end{array}$ & 0.1 & 20 & 25 & (In) & 30 & 39 & $(\mathrm{PT})$ \\
\hline \multirow{2}{*}{$\begin{array}{l}\text { Decis f-Luxx } 025 \text { EC, } \\
\text { (deltametrin) }\end{array}$} & 0.05 & 0 & 0 & (In) & 0 & 0 & (In) \\
\hline & 0.1 & 44 & 58 & (PT) & 33 & 42 & $(\mathrm{PT})$ \\
\hline $\begin{array}{l}\text { Confidor } 200 \mathrm{SL} \\
\text { (imidacloprid) }\end{array}$ & 0.006 & 48 & 72 & (MT) & 23 & 42 & $(\mathrm{PT})$ \\
\hline $\begin{array}{l}\text { Omite } 30 \mathrm{WP} \\
\text { (propargite) }\end{array}$ & 0.012 & 25 & 30 & (In) & 31 & 40 & $(\mathrm{PT})$ \\
\hline $\begin{array}{l}\text { Avaunt EC } \\
\text { (indoxacarb) }\end{array}$ & 0.005 & 0 & 0 & (In) & 0 & 0 & (In) \\
\hline
\end{tabular}

by the formation of resistance to insectocaricides, because it is known that this pesticide was mentioned as very toxic for predatory mites [3]. A similar conclusion can be attributed to the insecticides Decis f-Luxx 025 and BI-58 New.

The populations of apple orchard mites, subjected to chemical treatments, exhibit a less pronounced sensitivity to the studied insectocaricides in relation to the laboratory population of $N$. californicus. This mite proved to be sensitive to BI-58 New and Decis f-Luxx 025, while for the populations of $M$. occidentalis and $A$. orersoni, the doses of these insecticides recommended for use are inoffensive or poorly toxic. These mites are a constant component of the orchard acarifauna under permanent treatment with BI-58 New, Dursban 480 EC and Decis f-Luxx 025, during last 5-7 years. This proves that in the investigated populations of predatory mites there is a process of resistance formation to these insecticides. As can be seen from the above, predatory mites are less susceptible to Omite $30 \mathrm{WP}$ than phytophagous mites in the same agrocoenosis. The Confidor $200 \mathrm{SL}$ preparation is moderate or poorly toxic for predatory mites. At the same time, phytophagous mites are very resistant to it. It should be noted that according to the literature, fitoseides exhibit a different sensitivity to imidacloprid: from the highest to the lowest [3]. Some authors accept the idea that fitoseides mites develop tolerance or resistance to this product.

Analysis of the susceptibility of the Stethorus punctillum population, Chrysopa carnea and predatory mites shows that the long-term application of chemicals involves the selection of resistant individuals. Enhancement of 
resistance contributes to their survival and accumulation in agrocoenosis, which leads to the formation of acarifauna complex, which could control the development of harmful species. The research, of the last 15 years in this orchard, confirm that where no eruptions of the development of the phytophagous mites.

\section{CONCLUSION}

The assessment of the natural populations of pesticide-resistant entomoacariphagous is of particular value. Their use in practice is possible through laboratory reproduction and subsequent dispersion as well as their intra-areal redistribution. Regarding exposed information, it is opportune to monitor regularly the sensitivity to pesticides of both harmful and beneficial species.

\section{BIBLIOGRAPHY}

1. Amano H., Hasseb M. Recently-proposed methods and concepts of testing the effect of pesticides on the beneficial mite and insect species: study limitations and implications in IPM. Appl. Entomol. Zool. Vol. 36, 2001. No 1. P. 1-11.

2. Hassan S.A. Standard method to test the side-effects of pesticides on natural enemies of insects and mites developed by the IOBS/WPRS Working Group "Pesticides and Beneficial Organisms" Bull OEPP 15. 1985. P. 214-255.

3. James D.G. Beneficial arthropods in Washington hop yard: screening the impact of pesticides on survival and function. Final report for Washington State Commission for Pesticide Registration: March 2004.

\section{Батко М., Суменцова В., Ігорсополя О. Чутливість деяких видів ентомоакарифагів до інсектокарицидів, що застосовуються для захисту культури яблук}

Вивчено популяції яблуневого акарифага (Stethorus punctillum Weise, Chrysopa carnea Steph) i кліщів-хижаків (Amblyseius andersoni Chan, Metaseilus occidentalis Nesbit i Neoseiulus californicus Mc Gregor), які щонайменше 25 років піддавалися обробці пестицидами. Дослідження показують, що для иих популяцій найменш токсичними пестицидами $\epsilon$ Авант EC, Талстар 10 ЕС, Омайт 30 WP, Конфідор 200 SL, а найбільш токсичними пестицидами є Вертімек 018 ЕС та Дурсбан 480 ЕС для обох ентомофагів. Бі-58 Новий слабко токсичний для личинок C. сагпеа і високотоксичний для $N$. californicus в лабораторній культурі. Популяції акарифага в садах розвивають стійкість проти Бі-58 Новий, Дурсбан 480 ЕС і Децисфор-Люкс 025 ЕС в умовах пролонгованої обробки пестицидами. Відкриття природних популяцій ентомофагів, стійких проти пестицидів, має велике значення в зв'язку з його потенційним практичним використанням. 


\section{Батко М., Суменцова В., Игорсополя Е. Чувствительность некоторых видов энтомоакарифагов к инсектокарицидам, используемым в защите культуры яблок}

Изучены популяции яблоневого акарифага (Stethorus punctillum Weise, Chrysopa carnea Steph) и клещей-хищников (Amblyseius andersoni Chan, Metaseilus occidentalis Nesbit u Neoseiulus californicus Mc Gregor), которыe не менее 25 лет обрабатывались пестицидами. Исследования показывают, что для этих популяиий наименее токсичным пестицидом являются Авант EC, Талстар 10 EC, Омайт 30 WP, Конфидор 200 SL, а наиболее токсичными пестицидами являются Вертимек 018 ЕС, Дурсбан 480 ЕС для обоих энтомофагов. Би-58 Новый слабо токсичен для личинок С. сагпеа и высокотоксичен для N. californicus в лабораторной культуре. Популяции акарифага в садах развивают устойчивость против Би-58 Новый, Дурсбан 480 ЕС и Децисфор-Люкс 025 ЕС в условиях пролонгированной обработки пестицидами. Открытие природных популяций энтомофагов, устойчивых против пестицидов, имеет большое значение в связи с потенциальным практическим использованием. 